\title{
Prevalence of percutaneous injuries and associated factors among dental surgeons
}

\section{Prevalência de acidentes perfurocortantes e fatores associados entre cirurgiões-dentistas}

\begin{abstract}
Purpose: The practice of dentistry usually involves contact with secretions from the oral cavity through percutaneous injuries, which is a risk factor for the transmission of infections, especially hepatitis $B$, between the professional and patients. This study aimed to assess the prevalence of percutaneous injuries and associated factors among dental surgeons.

Methods: A total of 187 dental surgeons from the city of Pelotas, Brazil, participated in this study. Data concerning the socio-demographic aspects, occurrence of accidents, types of instruments, use of personal protective equipment, immunization coverage related to hepatitis $B$ and tests for serum conversion were collected through self-reported questionnaires. The data underwent descriptive analysis and chi-square testing or Fisher's exact test, with $P<0.05$. Results: The prevalence of percutaneous injuries was $59.8 \%$, and there was no association with the risk factors evaluated. Of the dentists interviewed, $97.3 \%$ had been vaccinated against hepatitis $\mathrm{B}$; however, only $86.2 \%$ had received the three recommended doses. The use of probes and handling needles were the most common causes of percutaneous injuries $(37.0 \%$ and $29.0 \%$, respectively).

Conclusion: The results showed that the prevalence of percutaneous injuries was high among dental surgeons, and there is a need for emphasis on the prevention of hepatitis B through the administration of the three vaccine doses and the use of personal protective equipment.

Key words: Occupational accidents; occupational risks; hepatitis B
\end{abstract}

\section{Resumo}

Objetivo: A prática dental geralmente envolve contato com secreções oriundas da cavidade bucal, através de injúrias percutâneas, sendo um fator de risco para transmissão de infecções entre profissionais e pacientes, especialmente hepatite B. Este estudo objetivou avaliar a prevalência de injúrias percutâneas e fatores associados entre cirurgiões-dentistas.

Métodos: Um total de 187 dentistas da cidade de Pelotas, RS, Brasil, participou deste estudo. Dados sobre aspectos socio-demográficos, ocorrência de acidentes, tipos de instrumentos, uso de equipamento de proteção, imunização relacionada à hepatite B e teste para avaliação de soroconversão foram coletados mediante questionário auto-administrado. Os dados foram submetidos à análise descritiva e testes do Qui-Quadrado de Pearson e Fisher para avaliar associação entre o desfecho e as variáveis preditoras, com nível de significância de 0,05.

Resultados: A prevalência de acidentes perfurocortantes foi de $59.8 \%$ e não houve associação com os fatores de risco avaliados. Dos dentistas participantes, $97.3 \%$ tinham sido vacinados conta a hepatite $\mathrm{B}$, entretanto, $86.2 \%$ tinham tomado as três doses recomendadas. $O$ uso de sondas e agulhas foram os maiores agentes causadores de acidentes, respectivamente $37.0 \%$ e $29.0 \%$.

Conclusão: Os resultados mostraram que a prevalência de injúrias percutâneas foi elevada entre dentistas e há necessidade de ênfase em prevenção de hepatite B através de adoção das três doses e uso de equipamento de proteção individual.

Palavras-chave: Acidentes ocupacionais; riscos ocupacionais; hepatite B

\author{
Fabiana Vargas-Ferreirab \\ Bianca Palma Santana ${ }^{a}$ \\ Sandra Beatriz Chaves Tarquinio a \\ Flávio Fernando Demarco a,b
} a Programa de Pós-Graduação em Odontologia,
Universidade Federal de Pelotas, Pelotas, RS, Brasil
b Programa de Pós-Graduação em Epidemiologia,
Universidade Federal de Pelotas, Pelotas, RS, Brasil

\author{
Correspondence: \\ Flávio Fernando Demarco \\ Universidade Federal de Pelotas \\ Programa de Pós-Graduação em \\ Odontologia e em Epidemiologia \\ Rua Gonçalves Chaves 457, $5^{\circ}$ andar \\ Pelotas, RS - Brasil \\ 96015-568 \\ E-mail: ffdemarco@gmail.com
}

Received: April 6, 2012

Accepted: June 15, 2012

Conflict of Interests: The authors state that there are no financial and personal conflicts of interest that could have inappropriately influenced their work.

Copyright: (C) 2012 Vargas-Ferreira et al.; licensee EDIPUCRS. This is an Open Access article distributed under the terms of the Creative Commons AttributionNoncommercial-No Derivative Works 3.0 Unported License. 


\section{Introduction}

Percutaneous injuries are a risk factor associated with pathogen transmission between health professionals, especially for dentists (1-3). The injuries are frequently a consequence of the limited field of vision for dentists during clinical work, which is also affected by patient movement (4). Furthermore, the environment in which dentists exert their professional activities harbors a large variability of microorganisms, originating from the patients' blood, saliva or respiratory system, which can be hazardous to the professional $(5,6)$.

The prevalence of percutaneous injuries was $84.6 \%$ among dentists in Araçatuba, Brazil (7). In Brasília (Brazil), another study also found a high prevalence $(86.5 \%)$ of these injuries in dentists (8). Several Brazilian studies have demonstrated a prevalence that varies from $26.0 \%$ to $80.8 \%$ $(3,6,9)$; such variability could be related to the difference in recall periods investigated, which could be 6 months, one year, or during the entire dentist's professional career (10).

Percutaneous exposition increases the probability of transmission of pathogens, such as the Hepatitis B virus (HBV) or the HIV virus $(2,11,13)$. Such injuries may also cause alterations in the psychosocial conditions of the injured professionals (14). In Brazil, the Ministry of Health estimates that $15 \%$ of the population had already contacted HBV and $1 \%$ exhibited chronic disease related to this virus, while worldwide, two billion individuals have already been infected with HBV (15).

In 2003, the Center for Disease Control (CDC) (16) stated that $\mathrm{HBV}$ is present in high concentrations in the circulating blood of humans and in low concentrations in other organic fluids, and it is approximately 100 times more infectious than $\mathrm{HIV}$ and 10 times higher than Hepatitis C virus. Hepatitis B is the major causal agent of acute and chronic liver disease, cirrhosis, and hepatocellular carcinoma (12), and dentists exhibit a 10 -fold greater risk of acquiring chronic Hepatitis $\mathrm{B}$ than the general population (5).

The most common method of preventing percutaneous injuries is to use adequate individual protection equipment ( 1 , $9,13,17)$ and to receive a vaccination against $\operatorname{HBV}(1,11$, $14,17)$ with posterior serum conversion analysis $(11)$.

In Brazil, there is little information about the occurrence of percutaneous injuries in dentists, and considering the potential harmful consequences of such injuries, new studies are needed to estimate the magnitude of the problem, which could help to develop strategies to prevent these injuries. Thus, this study sought to assess the prevalence of percutaneous injuries and associated factors among dentists in Southern Brazil. We believe that percutaneous injuries are common in daily practice.

\section{Methodology}

Sample

Prior to the study, it was submitted and approved by the Institutional Ethics Committee at the Federal University of
Pelotas. The study had a cross-sectional design, and it was carried out in the city of Pelotas, southern Brazil, between March and June 2009. Dentists with complete information $(n=276)$ registered in the Sectional Brazilian Dentistry Council, section of Pelotas, constituted the study population.

\section{Data collection}

For data collection, a self-applied closed questionnaire was used, including socio-demographic information (sex and self-reported skin color), professional characteristics (time since graduation, level of specialization, place of work), the use of individual protection equipment (mask, gloves and surgical cap), the occurrence of percutaneous injuries during professional life (and the causing instruments), information regarding vaccine coverage against Hepatitis B (yes/no and number of doses) and information related to the serum conversion examination (yes/no). The questionnaire did not include information that allowed for the identification of the dentist, and the study questions were pre-tested with dentists that did not enroll in the study.

The questionnaires were personally delivered to each dentist's office, and an explanation was given to the dentists about the importance of their participation and the objectives of the study. After one week, in a second visit to their offices, the questionnaires were recovered, together with the signed informed consent to participate in the study. If the dentists failed to sign the consent form or return the questionnaire, they were excluded from the study.

\section{Data Analysis}

The data underwent a descriptive analysis, and the associations between the time since graduation and the attendance of continuing education courses were tested with the chi-square or Fisher's exact tests (FET). The analyses were carried out with the Stata 10.0 (StataCorp, College Station, TX) software package. The level of significance was set at $P<0.05$.

\section{Results}

Of the dentists in practice in Pelotas (Rio Grande do Sul, Brazil) that were included in the sample, $187(68 \%)$ participated in the study. The losses and refusals were mainly due to the lack of questionnaire return or the lack of a signature on the informed consent form. Because the questionnaire was self-applied, some dentists did not answer all questions, and the number of answers for each question varied accordingly.

Table 1 presented the descriptive analysis of the study participants, showing that $52.4 \%$ were females and $96 \%$ were white. The time of graduation was most frequently within the past 10 years $(45.4 \%)$, and $64 \%$ of the dentists had been trained in some kind of formal continuing education (i.e., master's degree, specialized courses). In relation to the place of work, $66.1 \%$ spent more time in private practice. The prevalence of percutaneous injuries was $59.8 \%$, and $98 \%$ of the dentists reported to be vaccinated against Hepatitis $\mathrm{B}$, with $86.2 \%$ having received the three recommended 
doses. Concerning the blood exams to investigate the serum conversion (antibodies against HBV), only 46.6\% had undergone the examination.

Table 2 demonstrates the occurrence of percutaneous injuries and the association with the investigated independent variables. None of the variables under evaluation presented associations with the prevalence of injuries, and only the variable "location of work" was close $(P<0.06)$. Additionally, it was possible to verify that among those that suffered injuries, $84.9 \%$ had already received the three vaccine shots, and only $47.0 \%$ had undergone the serum conversion examination.

Table 1. Number of observations and frequencies in the studied variables among dentists ( $N=187)$. Pelotas, Rio Grande do Sul, Brazil, 2009

\begin{tabular}{|c|c|c|}
\hline Variables & $\mathrm{n}^{*}$ & $(\%)$ \\
\hline Sex & 187 & \\
\hline Male & 89 & 47.6 \\
\hline Female & 98 & 52.4 \\
\hline Self-reported skin color & 186 & \\
\hline White & 180 & 96.8 \\
\hline Light black skinned & 4 & 2.1 \\
\hline Black & 2 & 1.1 \\
\hline Time since graduation (years) & 185 & \\
\hline$\leq 10$ & 84 & 45.5 \\
\hline $11-20$ & 43 & 23.2 \\
\hline $21-30$ & 28 & 15.1 \\
\hline$>30$ & 30 & 16.2 \\
\hline Level of specialization & 182 & \\
\hline General dentists & 66 & 36.3 \\
\hline Specialization/Master's Degree & 116 & 63.7 \\
\hline Place of work & 183 & \\
\hline Only Private & 121 & 66.1 \\
\hline Only Public & 17 & 9.3 \\
\hline Private/Public & 22 & 12,0 \\
\hline Professor & 23 & 12.6 \\
\hline Percutaneous injuries & 184 & \\
\hline No & 74 & 40.2 \\
\hline Yes & 110 & 59.8 \\
\hline Facial mask use & 187 & \\
\hline No & 13 & 7.0 \\
\hline Yes & 174 & 93.0 \\
\hline Gloves usage & 184 & \\
\hline No & 5 & 2.8 \\
\hline Yes & 179 & 97.2 \\
\hline Surgical cap usage & 185 & \\
\hline No & 27 & 14.6 \\
\hline Yes & 108 & 58.4 \\
\hline Sometimes & 50 & 27.0 \\
\hline Vaccination against Hepatitis B & 186 & \\
\hline No & 5 & 2.7 \\
\hline Yes & 181 & 97.3 \\
\hline Number of doses & 181 & \\
\hline 1 & 4 & 2.2 \\
\hline 2 & 21 & 11.6 \\
\hline 3 & 156 & 86.2 \\
\hline Serum conversion testing & 176 & \\
\hline No & 94 & 53.4 \\
\hline Yes & 82 & 46.6 \\
\hline
\end{tabular}

Table 2. Prevalence of percutaneous injuries and associated factors ( $N=187$ ). Pelotas, Rio Grande do Sul, Brazil, 2009

\begin{tabular}{|c|c|c|}
\hline \multirow{2}{*}{ Variables } & \multicolumn{2}{|c|}{ Percutaneous injuries } \\
\hline & $\mathrm{n}^{*}(\%)$ & $P$ \\
\hline \multicolumn{3}{|l|}{ Sex } \\
\hline Male & $54(49.0)$ & \multirow{3}{*}{$0.43^{(1)}$} \\
\hline Female & $56(51.0)$ & \\
\hline Total & 110 & \\
\hline \multicolumn{3}{|l|}{ Self-reported skin color } \\
\hline White & $107(98.2)$ & \multirow{3}{*}{$0.22^{(2)}$} \\
\hline Light black skinned & $2(1.8)$ & \\
\hline Total & 109 & \\
\hline \multicolumn{3}{|l|}{ Time since graduation (years) } \\
\hline$\leq 10$ & $43(39.5)$ & \multirow{5}{*}{$0.18^{(1)}$} \\
\hline $11-20$ & $26(23.8)$ & \\
\hline $21-30$ & $18(16.5)$ & \\
\hline$>30$ & $22(20.2)$ & \\
\hline Total & 109 & \\
\hline \multicolumn{3}{|l|}{ Level of specialization } \\
\hline General dentist & $41(38.3)$ & \multirow{3}{*}{$0.38^{(1)}$} \\
\hline Specialization/Master's Degree & $66(61.7)$ & \\
\hline Total & 107 & \\
\hline \multicolumn{3}{|l|}{ Place of work } \\
\hline Only Private & $73(68.0)$ & \multirow{5}{*}{0.06} \\
\hline Only Public & $9(8.3)$ & \\
\hline Private/Public & $17(15.7)$ & \\
\hline Professor & 9 (8.3) & \\
\hline Total & 108 & \\
\hline \multicolumn{3}{|l|}{ Facial mask use } \\
\hline No & $100(90.9)$ & \multirow{3}{*}{$0.19^{(1)}$} \\
\hline Yes & $10(9.1)$ & \\
\hline Total & 110 & \\
\hline \multicolumn{3}{|l|}{ Gloves usage } \\
\hline No & $103(96.3)$ & \multirow{3}{*}{$0.64^{(2)}$} \\
\hline Yes & $4(3.7)$ & \\
\hline Total & 107 & \\
\hline \multicolumn{3}{|l|}{ Surgical cap usage } \\
\hline No & $31(28.7)$ & \multirow{4}{*}{$0.63^{(1)}$} \\
\hline Yes & $63(58.3)$ & \\
\hline Sometimes & $14(13.0)$ & \\
\hline Total & 108 & \\
\hline \multicolumn{3}{|l|}{ Vaccination against Hepatitis B } \\
\hline No & $4(3.7)$ & \multirow{3}{*}{$0.64^{(2)}$} \\
\hline Yes & $105(96.3)$ & \\
\hline Total & 109 & \\
\hline Number of doses & & \\
\hline 1 & $4(3.8)$ & \\
\hline 2 & $12(11.3)$ & $0.30^{(2)}$ \\
\hline 3 & $90(84,90)$ & \\
\hline Total & 106 & \\
\hline Exam for conversion & & \\
\hline No & $54(53,00)$ & 098 (1) \\
\hline Yes & $48(47,00)$ & 0,98 \\
\hline Total & 102 & \\
\hline Immunization against Hepatitis B & & \\
\hline No & $2(3,45)$ & $0.06^{(2)}$ \\
\hline Yes & $56(96,55)$ & 0,06 (2) \\
\hline Total & 58 & \\
\hline
\end{tabular}


When reporting the instruments that caused the accidents, the dental explorer and needles were reported by $37.0 \%$ and $29.0 \%$, respectively, while $13 \%$ of dentists reported curettes, $5 \%$ reported burs, and 16\% reported other instruments (Fig. 1).

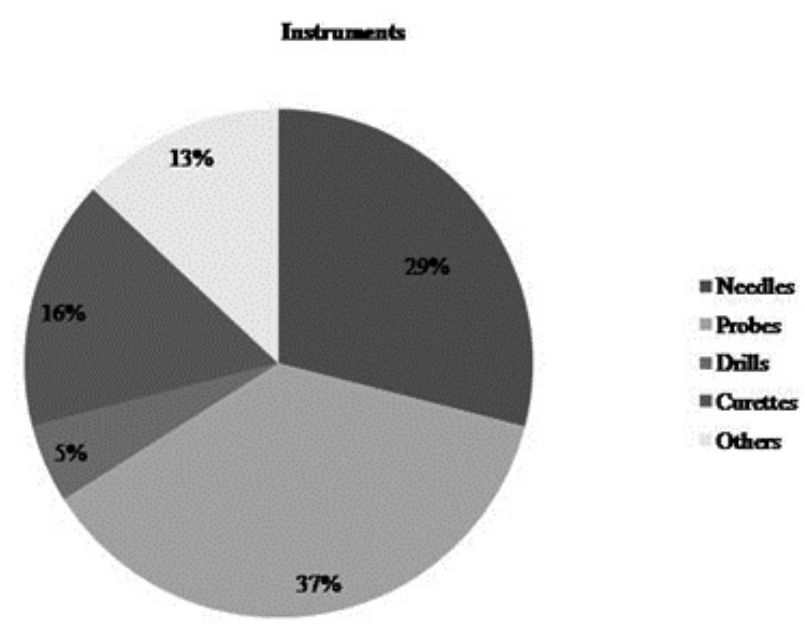

Fig. 1. Instruments related to the frequency of percutaneous injuries

\section{Discussion}

The results of this study indicate a high prevalence of percutaneous injuries among dentists in Pelotas, raising the need for preventive measures to avoid these incidents. Such injuries are associated with potential harmful risks as a consequence of contamination from microorganisms present in the blood, saliva or respiratory system of the patients (5). Highlighting this increased risk, several studies worldwide have demonstrated a higher prevalence of HBV in dentists compared to the general population (17).

The prevalence of percutaneous injuries in dentists has scarcely been investigated in Brazil $(3,6-9)$. Considering previous Brazilian studies, the prevalence reported in our investigation $(59.8 \%)$ is similar to the study in which a prevalence of $64.3 \%$ was detected (16). Compared to the other studies, our findings demonstrated a lower prevalence of these incidents $(3,7,9)$. The main factor that accounts for such results is related to the recall period in the occurrence of the percutaneous incidents (six months, one year, the entire professional life) (3), and this could underestimate or overestimate the condition evaluated.

The distribution of professionals that suffered these injuries, according to sex, is variable in the literature, although females are more likely to be injured $(3,4,6,8,18)$. In this study, women exhibited a higher prevalence of injuries, but this difference was not statistically significant.

Despite a lack of significance, a higher rate of accidents $(40.0 \%)$ were detected in professionals with less than 10 years of clinical experience (3), and this finding could indicate that a greater length of time in clinical practice may be a protective factor against the occurrence of accidents (3).
Nevertheless, in a study performed with 80 dentists in Florianopólis, Brazil, a direct relationship was found between the duration of professional clinical activity and an increased probability of injuries (9).

In this study, $93.0 \%$ of the surveyed dentists reported the routine use of facial masks, while $97.0 \%$ regularly used gloves and only $58.0 \%$ used a surgical cap; these rates are similar to those of previously reported studies $(3,6,9)$. Contrarily, in Nigeria, a survey with 185 dentists demonstrated low rates of use of gloves and facial masks (29.4\% and $52.7 \%$, respectively) (19). It has already been established that individual protection equipment should be mandatory to minimize the chance of pathogen transmission between the patient and dentist, avoiding the possibility of crossed infection $(6,7,14,15,20)$. Other important protection barriers that are mandatory in dental clinics include instrument sterilization and a program of active immunization for professional and auxiliary personnel $(15,17)$.

The instrument that is most frequently involved in accidents is the explorer, followed by needles. Other reports presented in the literature have found similar results $(4,6,7,10)$. Dentists from Montes Claros, MG, Brazil, reported higher frequencies of injuries with burs, explorers and needles (10). The recommendations from the CDC for infection control include not only the use of individual protection equipment but also the correct handling of instruments and materials (16).

Among those dentists surveyed in this study, 97.0\% were already vaccinated against HBV. Previous inquires on dentists' immunization against HBV showed similar rates $(3,10,12,17)$, which were higher than the immunization rate found in Nigeria (50.0\%) (19). Importantly, the vaccine against HBV has been available since 1982, and since 1990, it has been recommended for all health professionals whose activities frequently expose them to have contact with blood (21). The vaccine is considered to have a high efficacy without toxicity, and it rarely produces adverse effects (11).

In our survey in southern Brazil, almost $85.0 \%$ of dentists had already received the recommended three vaccine shots. Such coverage is higher than the coverage observed in other Brazilian studies in Florianopólis (56\%) and Belo Horizonte (73.8\%) (12,20). In 241 dentists from Montes Claros, MG, Brazil, complete vaccination was observed in $91.0 \%$; this result was credited to the high comprehension of these dentists regarding the importance of vaccination for the primary prevention of Hepatitis B (10). The Ministry of Health recommends that the complete vaccine regimen of three shots should be performed for all health workers. The second shot should be taken after 1-2 months, and the third should be administered 6 months after the first dose. Following such a protocol, 95\% of the vaccinated professionals will develop antibodies, and in these individuals, protection against hepatitis is almost $100 \%$ (21).However, it is highly recommended that a serological examination is conducted to assess antibody conversion (21). 
Even though the majority (84.9\%) of the dentists surveyed in Pelotas had already been vaccinated against HBV with three doses, only $47.0 \%$ had performed the serological examination. The present finding is greater than the results found for Belo Horizonte and Montes Claros (14.8\% and $12.8 \%$, respectively) $(3,12)$, and these low rates indicate that dentists do not regularly undergo serological examination. The factors that favor a failure of the immunological response, such as concomitant pathologies and the storing and handling conditions of the vaccines, are well known (11). Thus, the verification of serological conversion is essential for the health professional, and it is recommended that serological tests be performed one to three months after completing the vaccination regimen (16).

This study may have been limited by its cross-sectional design, as it was not possible to completely establish the temporal causal nexus. However, this type of investigation is applicable as a preliminary "picture" of the studied condition. Longitudinal studies that follow up with the selected individuals are recommended to determine the more frequent risk factors and the methods that may prevent percutaneous injuries (5). In addition, cross-sectional studies serve to maximize the understanding among dentists and their adhesion to the precautionary measures (3).

Another limitation is related to the method of questionnaire application. Self-applied questionnaires increase the prevalence of memory bias (6). Differently from other studies, the occurrence of percutaneous injuries was not associated with the time in clinical practice (professional life) in this study. Small accidents tend to be forgotten, generating an underestimation $(3,6)$.
Furthermore, because this study was based on selfreported data, the reported prevalence of vaccination may have been overestimated. When professionals are evaluated/ questioned, they often change their behavior (3); that is, individuals tend to report that they adhere to recommended protocols, even when they do not (14). Nevertheless, considering that the vaccination against $\mathrm{HBV}$ is composed of three doses, performed on pre-determined dates and reported on a vaccination card, it is plausible that those that claimed complete vaccination were truthful (14).

\section{Conclusion}

The results presented here allow for the conclusion that a high rate $(59.8 \%)$ of dentists in Pelotas, southern Brazil, suffered percutaneous injuries and potential biological contamination. Additionally, the low reported adhesion to the serological testing recommendations against Hepatitis $\mathrm{B}$ is troublesome.

Therefore, the constant distribution of information to professionals about the risks of contamination with dental instruments and the complete vaccination scheme should be provided, followed by serum conversion testing.

\section{Acknowledgments}

The authors would like to thank all the dentists for their participation in this study and Amália Bielemann, Thiago Ribeiro and Vinícius Sommer for delivering the questionnaires.

\section{References}

1. Angelo AR, Queiroga AS, Gonçalves LFF, Santos SD, Sousa CS, Soares MSM. [Hepatitis B: Knowledge and practice of odontology students at UFPB]. Pesq Bras Odontoped Clin Integr 2007;7:21 1-6.

2. Cleveland JL, Barker LK, Cunv EJ, Panlilio AL. Preventing percutaneous injuries among dental health care personnel. J Am Dent Assoc 2007;138:169-78.

3. Martins AMEBL, Barreto SM, Rezende VLS. [Occupational accidents with sharp instruments of dental surgeons]. Rev Bras Med Trab 2004;2:267-74.

4. Ramos-Gomez F, Ellison J. Greenspan D, Bird W, Lowe S. Gerberding JL. Accidental exposures to blood and body fluids among health care workers in dental teaching clinics: a prospective study. J Am Dent Assoc 1997;128:1253-61.

5. Araujo MWB, Andreana S. Risk and prevention of transmission of infectious diseases in Dentistry. Quintessence Int 2002;33:376-82.

6. Garcia LP, Blank VLG. [Prevalence of occupational exposures to potentially infectious materials among dentists and dental assistants]. Cad Saúde Pública 2006;22:97-108.

7. Garbin AJI,Presta AA, Garbin CAS, Lima DC. [Occurrence of occupational accidents and conducts in the dental practice]. Rev Cub Salud Trabajo 2006;7:29-33.

8. Caixeta RB, Barbosa-Branco A. [Work-related accidents in health care workers from public hospitals in Brasilia, Brazil, 2002/2003]. Cad. Saúde Pública 2005;21:737-46.

9. Teixeira CS, Pasternak-Júnior B, Silva-SousaYT, Correa-Silva SR. [Pre and post-exposure preventive measures to injuries caused by percutaneous instruments during dental practice]. Rev Odonto Ciênc 2008;23:10-4.

10. Martins AMEBL, Pereira RD, Ferreira RC. [Compliance with occupational post-exposure protocol for injuries among dental surgeons]. Rev Saúde Pública 2010;44:529-40.

11. Ferreira CT, Silveira TR. [Viral Hepatitis: epidemiological and preventive aspects]. Rev Bras Epidemiol 2004;7:473-87.

12. Resende VLS, Abreu MHG, Paiva SM, Teixeira R, Pordeus IA. Concerns regarding hepatitis B post-vaccination test among Brazilian dentists. Virol J 2010;7(1):1-9. 
13. Shah SM, Merchant AT, Dosman JA. Percutaneous injuries among dental professionals in Washington State. BMC Public Health. 2006 Oct; 6:269.

14. Garcia LP, Blank VLG. [Management of occupational exposures to potentially infectious materials in dentistry]. Rev Saúde Pública 2009;42:279-86.

15. Mahboobi N, Agha-Hosseini F, Mahboobi N, Safari S, Lavanchy D, Alavian SM. Hepatitis B virus infection in dentistry: a forgotten topic. J Viral Hepat 2010;17:307-16.

16. CDC. Recommendations and Reports. Prevention and control of infections with hepatitis virus in correctional settings. Morbidity and Mortality Weekly Report 2003;52:1.

17. Martins AMEBL, Barreto SM. [Hepatitis B vaccination among dentists]. Rev Saúde Pública 2003;37:333-8.

18. Saliba NA, Moimaz SAS, Vilela RM, Blanco MB. [Women workforce in Dentistry - quantiqualitative approach]. Rev Bras Odont 2002;59:400-2.

19. Sofola OO, Savage KO. Assessment of the compliance of Nigerian dentists with infection control: a preliminary study. Infect Control Hosp Epidemiol 2003;24:737-40.

20. Garcia LP, Fachini LA. [Hepatitis B vaccination among primary health care workers]. Cad Saúde Pública 2008;24:1130-40.

21. Brasil. Ministério da Saúde. Serviços odontológicos: Prevenção e Controle de riscos. Agência Nacional de Vigilância Sanitária. Brasília: Ministério da Saúde; 2002. 